\title{
Temperature And Humidity Control Based On Quail Eggs
}

\author{
Dian Efytra Yuliana ${ }^{\mathrm{a}, 1, *}$ \\ a Department of Electrical Engineering Faculty of Enginering Universitas Islam Kadiri-Kediri, Jl. Sersan Suharmaji \\ No.38 Manisrenggo District City, Kediri, 64128, Indonesia \\ ${ }^{1}$ dianefytra@uniska-kediri.ac.id
}

\begin{tabular}{|c|c|}
\hline & ABSTRACT \\
\hline $\begin{array}{l}\text { Keywords } \\
\text { Arduino } \\
\text { DHT } 11 \\
\text { LCD } \\
\text { Blower } \\
\text { Heater }\end{array}$ & $\begin{array}{l}\text { In quail DOQ cultivation after the quail eggs hatch, DOQ (Day Old Quail) quail chicks } \\
\text { need a warm place as a substitute for the mother to maintain the temperature of the body, } \\
\text { because in this phase quail chicks have not been able to adjust to room temperature. If } \\
\text { the temperature is not suitable, it will cause quail death. From these problems, a quail } \\
\text { DOQ cage control system was made using microcontroller. This system consist of a } \\
\text { DHT11 sensor as a detector of temperature and humidity, and Arduino as a controller of } \\
\text { the system. The heat source in the DOQ room uses a DC bulb equipped with a blower to } \\
\text { spread the heat, the signal from the sensor is used as a parameter controlling the } \\
\text { temperature and humidity of the cage by adjusting pwm on Arduino when the } \\
\text { temperature in the cage is too hot or less hot and the humidity is less humid. To display } \\
\text { the temperature of the border space, a } 16 \times 2 \mathrm{LCD} \text { display is used. From the fuzzy logic } \\
\text { test results obtained an error percentage of } 1 \% \text { humidity of } 2 \% \text { and a mortality rate of } \\
0 \% \text { and without using fuzzy logic a mortality rate of } 20 \% \text {. }\end{array}$ \\
\hline
\end{tabular}

\section{Introduction}

Breeding is an attempt to breed living things, one of which is quail. In the hatching with a considerable amount need to be used a tool to hatch the eggs. After the quail eggs hatch, DOQ (Day Old Quail) quail chicks need a warm place as a substitute for its mother to maintain its body temperature, because in this phase quail chicks have not been able to adjust to the room temperature of $25^{\circ} \mathrm{C}-30^{\circ} \mathrm{C}$. In this process the quail chicks need approximately 10 days to be able to adjust the ambient temperature. At the age of 10 days feathers on quails have grown almost evenly. [1][2]

The temperature needed by the quail DOQ is in accordance with the development of growing quails, i.e. the age gets older the temperature in the cage will be higher, because the density of the quail in the cage will affect the temperature inside the cage. When the quail is more that 10 days old, the quail chicks are able to adjust to the ambient temperature, so that the quails do not need to be warmed up anymore, and are ready to enter the next stage, which is an enlarged or laying cage.[3]

In this breeding many farmers have used tools to warm quail seeds after the hatching process. But still in a manual way, which utilizes the effect of heat from incandescent lamps, by using a thermometer as a indicator of the temperature. It is not often that they experience losses because of the many quail seeds that die due to jostling when the temperature in the cage is not appropriate, it too hot or less hot. In this case the breeder feels confused because when using incandescent lamps, that is difficult in getting incandescent lamps with the appropriate temperature effect, and when the temperature is not high enough the breeder must use a large incandescent bulb so that the temperature is what is needed by the quail seeds.

To simplify all this, a quail DOQ cage control system using a microcontroller is made[4]. This system consist of a DHT11 sensor as a detector of temperature and humidity, and Arduino as a controller of the system. The heat source in the DOQ room uses a DC bulb equipped with a blower to spread the heat, the signal from the sensor is used as a parameter controlling the temperature and humidity of the cage by adjusting pwm on Arduino when the temperature in the cage is too hot or less hot and the humidity is too humid. To display the temperature of the border space, a $16 \times 2 \mathrm{LCD}$

149 | P a g e 
display is used. The temperature used at the age of 0-10 days at manual temperature control is approximately $34^{\circ} \mathrm{C}-38^{\circ} \mathrm{C}$, with humidity between $40 \% \mathrm{RH}-70 \% \mathrm{RH}$.

\section{The Proposed Method/Algorithm}

In this research method, activities can be divided into two part, namely hardware design and software design. Hardware design includes making system block diagrams and component assembly. After the hardware design is complete then the software design continues, which can be integrated into the hardware device so that the data can be displayed in real-time.

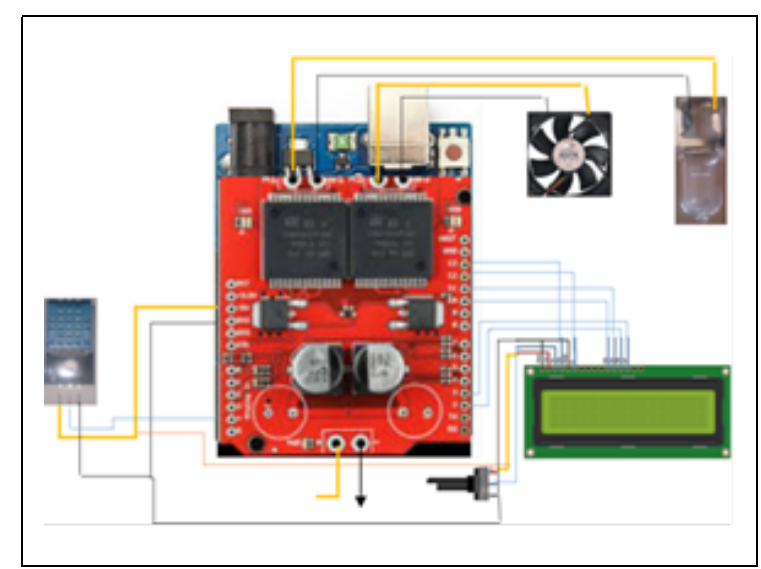

Fig. 1. Arduino Uno pin connection with other device

In hardware design the DHT 11 sensor functions to provide input for reading temperature and humidity inside the enclosure to Arduino. Heater and Blower as an Output whose function is to regulate temperature and humidity in the cage according to the input values that have been set. Heater and Blower will be regulated by PWM through the motor driver[5]. The LCD functions as a data displayer (displaying) the temperature and humidity inside the cage. Figure 1

\section{Method}

Fuzzification process after reading the temperature and humidity sensor values in the cage chamber [6]. Conversion of digital data to decimal in the form of voltage is used for input to control the work of the heater and blower through the driver.figure 2

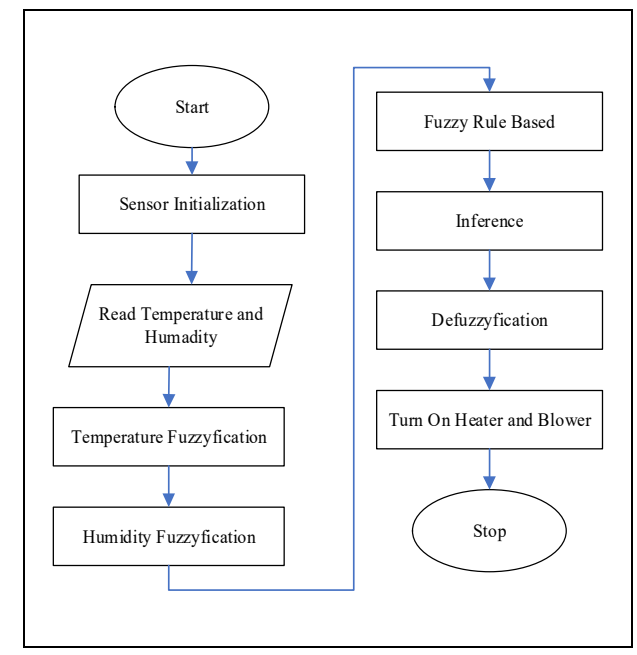

Fig. 2. Fuzzy logic flowchart 
JEEMECS (Journal of Electrical Engineering, Mechatronic and Computer Science) ISSN 2614-4859

Vol. 3, No. 2, August 2020, pp. 149-156

d. https://doi.org/10.26905/jeemecs.v3i2.4354

\subsection{Fuzzyfication}

In the fuzzification process the membership function in the form of temperature has 3 linguistic values, namely warm, rather hot, and hot.figure 3

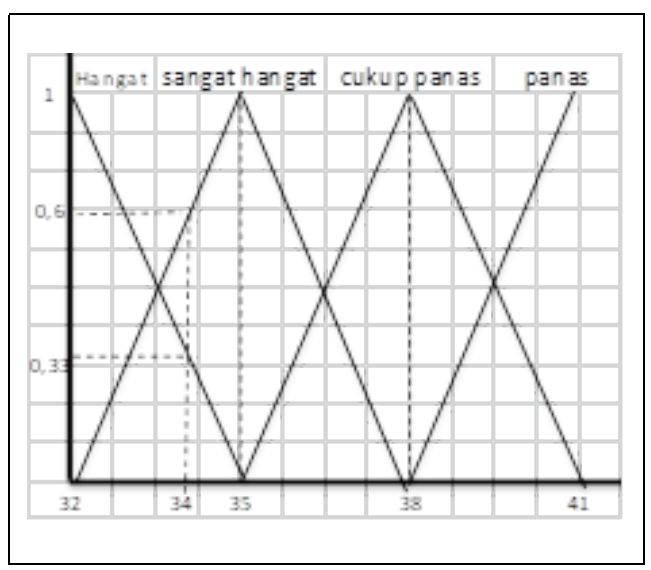

Fig. 3. Fuzzification temperature curve.

Whereas the membership function in the form of humidity also has 3 linguistic values, namely dry, rather dry, and normal.figure 4

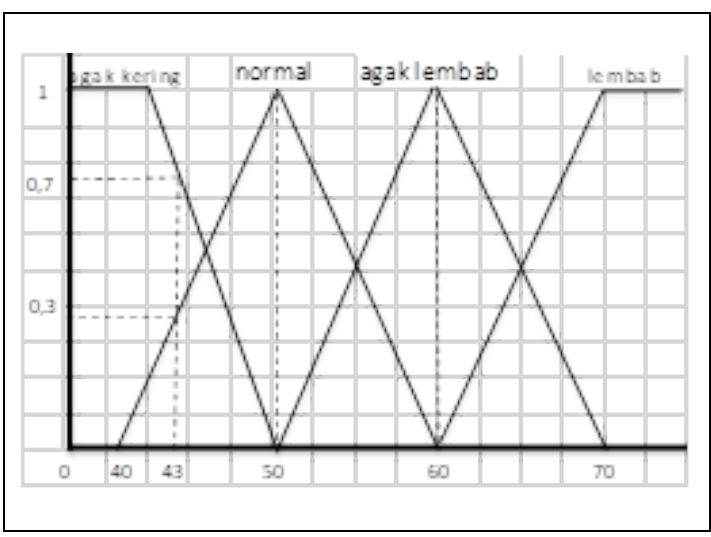

Fig. 4. Fuzzyfication Humidity Curve

\subsection{Rule Base Fuzzy}

At this stage, each output from the fuzzification stage in the form of degrees of temperature and humidity sensor membership will be combined using rule evaluation figure 5

\subsection{Defuzzyfikasi}

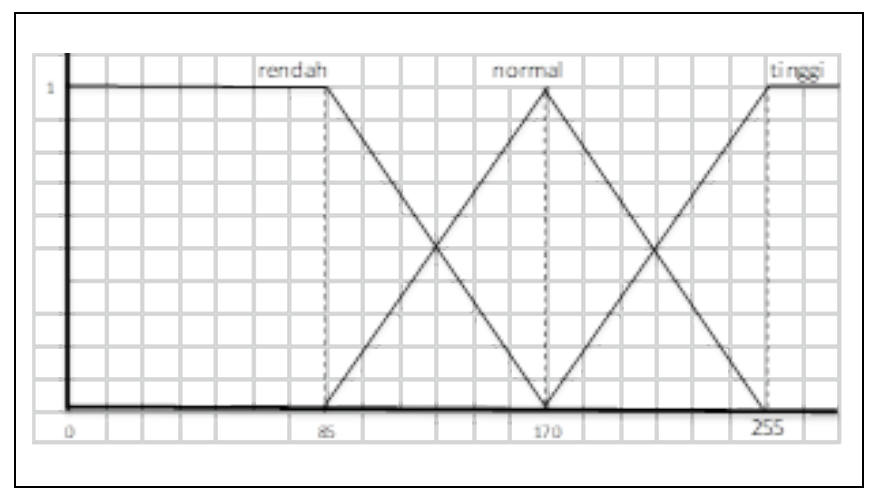

Fig. 5. Figure Membership Function Output

151 | P a g e 


\section{Results and Discussion}

\subsection{DHT11 Sensor Calibration Data}

Table 1. DHT11 Sensor Calibration Table

\begin{tabular}{|c|c|c|c|c|c|c|c|}
\hline \multirow[b]{2}{*}{ No. } & \multirow{2}{*}{$\begin{array}{c}\text { Thermometer } \\
\text { Analog } \\
\left({ }^{\circ} \mathrm{C}\right)\end{array}$} & \multicolumn{2}{|c|}{ DHT 11} & \multicolumn{2}{|c|}{ Hygrometer } & \multicolumn{2}{|c|}{ Eror } \\
\hline & & $\begin{array}{l}\text { Temp } \\
\left({ }^{\circ} \mathrm{C}\right)\end{array}$ & $\begin{array}{c}\text { Humidity } \\
\text { (\% RH) }\end{array}$ & $\begin{array}{l}\text { Temp } \\
\left({ }^{\circ} \mathrm{C}\right)\end{array}$ & $\begin{array}{c}\text { Humidity } \\
\text { (\% RH) }\end{array}$ & $\begin{array}{l}\text { Temp } \\
\left({ }^{\circ} \mathrm{C}\right)\end{array}$ & $\begin{array}{c}\text { Humidity } \\
\text { (\% RH) }\end{array}$ \\
\hline 1 & 25 & 25 & 40 & 25 & 45 & 0 & 1 \\
\hline 2 & 26 & 26 & 41 & 27 & 42 & 0 & 2 \\
\hline 3 & 27 & 26 & 43 & 28 & 41 & 3 & 4 \\
\hline 4 & 28 & 27 & 45 & 28 & 45 & 3 & 0 \\
\hline 5 & 29 & 28 & 47 & 30 & 46 & 3 & 2 \\
\hline 6 & 30 & 29 & 49 & 31 & 47 & 3 & 4 \\
\hline 7 & 31 & 31 & 50 & 31 & 49 & 0 & 2 \\
\hline 8 & 32 & 32 & 52 & 32 & 52 & 0 & 0 \\
\hline 9 & 33 & 32 & 55 & 34 & 53 & 3 & 3 \\
\hline 10 & 34 & 33 & 58 & 34 & 58 & 2 & 0 \\
\hline 11 & 35 & 35 & 60 & 35 & 60 & 2 & 0 \\
\hline 12 & 36 & 36 & 63 & 36 & 62 & 0 & 1 \\
\hline 13 & 37 & 37 & 65 & 36 & 62 & 0 & 4 \\
\hline 14 & 38 & 38 & 68 & 38 & 64 & 0 & 5 \\
\hline 15 & 39 & 39 & 70 & 40 & 70 & 2 & 0 \\
\hline 16 & 25 & 25 & 40 & 25 & 45 & 0 & 1 \\
\hline & \multicolumn{5}{|c|}{ Mean } & 1 & 2 \\
\hline
\end{tabular}

Based on the calibration test temperature and humidity generated error values from the DHT11 sensor that is for temperature $1 \%$ and for humidity $2 \%$.

\subsection{Research Results Using Annual Cages Without Tools}

Table 2. Manual Cage Trial Results

\begin{tabular}{|c|c|c|c|c|c|c|c|}
\hline \multirow[b]{2}{*}{ Day } & \multicolumn{2}{|c|}{07.00} & \multicolumn{2}{|c|}{12.00} & \multicolumn{2}{|c|}{17.00} & \multirow[b]{2}{*}{$\begin{array}{l}\text { Quail } \\
\text { Total }\end{array}$} \\
\hline & $\begin{array}{c}\text { Temp } \\
\left({ }^{\circ} \mathrm{C}\right)\end{array}$ & $\begin{array}{c}\text { Humidity } \\
\text { (\% RH) }\end{array}$ & $\begin{array}{c}\text { Temp } \\
\left({ }^{\circ} \mathrm{C}\right)\end{array}$ & $\begin{array}{c}\text { Humidity } \\
\text { (\% RH) }\end{array}$ & $\begin{array}{l}\text { Temp } \\
\left({ }^{\circ} \mathrm{C}\right)\end{array}$ & $\begin{array}{c}\text { Humidity } \\
\text { (\% RH) }\end{array}$ & \\
\hline 1 & 34 & 37 & 36 & 38 & 38 & 35 & 10 \\
\hline 2 & 32 & 38 & 36 & 37 & 38 & 34 & 10 \\
\hline 3 & 34 & 36 & 39 & 36 & 38 & 34 & 10 \\
\hline 4 & 38 & 39 & 35 & 39 & 38 & 35 & 9 \\
\hline 5 & 36 & 37 & 37 & 37 & 38 & 36 & 9 \\
\hline 6 & 36 & 35 & 38 & 38 & 38 & 34 & 9 \\
\hline 7 & 32 & 36 & 38 & 36 & 38 & 35 & 9 \\
\hline 8 & 34 & 37 & 38 & 37 & 38 & 36 & 8 \\
\hline 9 & 32 & 39 & 36 & 38 & 38 & 37 & 8 \\
\hline 10 & 32 & 35 & 37 & 36 & 38 & 38 & 8 \\
\hline
\end{tabular}

In a manual study the temperature and humidity in the cage tends to change because it is influenced by outside temperatures and the size of the ventilation space of the cage, breeders must actively control the temperature and humidity in the cage to be maintained. In this trial quail deaths reached 2 of the total number of 10 quails within 10 days of the experiment. Quail death caused by high cage room temperature in the second seassion, at 12.00 WIB. The temperature at this hour is also influenced by a fairly high outside temperature.

\subsection{Overall Research Results for Enclosures with Automatic Temperature}

Research by controlling temperature and humidity automatically the temperature is set between $32^{\circ} \mathrm{C}-38^{\circ} \mathrm{C}$ i.e when the temperature is less than $32^{\circ} \mathrm{C}$ then the pwm will be fully regulated ie 255 with an output voltage of $12 \mathrm{~V}$ and when the temperature is more than $38^{\circ} \mathrm{C}$ then the pwm at set 0 . And in the humidity is low or below $40 \% \mathrm{RH}-70 \% \mathrm{RH}$, i.e. when humidity is low or below $40 \% \mathrm{RH}$ then the pwm will be set with pwm 0, and when the humidity is high or greater than $70 \% \mathrm{RH}$ the pwm is set full which is 255 
Table 3. Result of Temperature and Humidity Control of The Cage at 07.00 WIB

\begin{tabular}{ccccc}
\hline \multicolumn{5}{c}{$\mathbf{0 7 . 0 0}$} \\
\hline No. & $\begin{array}{c}\text { Temp. } \\
\left({ }^{\mathbf{C}} \mathbf{C}\right)\end{array}$ & PWM & $\begin{array}{c}\text { Humidity } \\
\text { (\% RH) }\end{array}$ & PWM \\
\hline 1 & 32 & 217,22 & 60 & 178,33 \\
2 & 32 & 212,69 & 54 & 201,33 \\
3 & 33 & 214,35 & 51 & 299,00 \\
4 & 34 & 209,00 & 51 & 209,00 \\
5 & 32 & 215,52 & 45 & 212,83 \\
6 & 33 & 214,35 & 53 & 299,00 \\
7 & 33 & 226,25 & 36 & 226,25 \\
8 & 31 & 255,00 & 37 & 209,00 \\
9 & 33 & 212,65 & 53 & 203,25 \\
10 & 32 & 235,36 & 44 & 239,67 \\
\hline
\end{tabular}

The second temperature and humidity control data is 12.00. the temperature tends to be higher than the first data, because during the day the outside temperature tends to be higher and unstable, so the temperature and humidity in the cage are also higher between $32^{\circ} \mathrm{C}-37^{\circ} \mathrm{C}$ with humidity of $35 \% \mathrm{RH}-58 \% \mathrm{RH}$ due to being affected outside temperature.

Table 4. Results of Temperature and Humidity Control of The Cage at 12.00 WIB

\begin{tabular}{ccccc}
\hline \multicolumn{5}{c}{$\mathbf{1 2 . 0 0}$} \\
\hline No. & $\begin{array}{c}\text { Temp. } \\
\left({ }^{\mathbf{0}} \mathbf{C}\right)\end{array}$ & PWM & $\begin{array}{c}\text { Humidity } \\
\text { (\% RH) }\end{array}$ & PWM \\
\hline 1 & 34 & 206,28 & 56 & 195,20 \\
2 & 33 & 217,18 & 49 & 214,75 \\
3 & 34 & 206,17 & 55 & 197,50 \\
4 & 34 & 209,48 & 49 & 210,58 \\
5 & 33 & 212,65 & 53 & 203,25 \\
6 & 34 & 206,28 & 56 & 195,20 \\
7 & 36 & 182,77 & 56 & 194,63 \\
8 & 35 & 197,50 & 50 & 206,17 \\
9 & 32 & 214,20 & 58 & 186,35 \\
10 & 34 & 226,25 & 41 & 179,89
\end{tabular}

On the results of taking data control temperature and humidity at 17.00 . the temperature in the cage tends to be lower between $32^{\circ} \mathrm{C}-33^{\circ} \mathrm{C}$ with humidity between $35 \% \mathrm{RH}-60 \% \mathrm{RH}$ because in the afternoon the outside temperature tends to be stable and not too hot. This temperature and humidity also lasted until the next day. The difference with a manual cage that must monitor temperature and humidity at all times.

Table 5. Result of The Temperature and Humidity Control of The Cage at 17.00 WIB

\begin{tabular}{ccccc}
\hline \multicolumn{5}{c}{$\mathbf{1 7 . 0 0}$} \\
\hline No. & $\begin{array}{c}\text { Temp. } \\
(\mathbf{} \mathbf{C})\end{array}$ & PWM & $\begin{array}{c}\text { Humidity } \\
(\mathbf{\%} \text { RH) }\end{array}$ & PWM \\
\hline 1 & 32 & 217,22 & 60 & 178,33 \\
2 & 33 & 212,23 & 54 & 200,38 \\
3 & 33 & 213,36 & 58 & 188,88 \\
4 & 32 & 213,26 & 57 & 189,83 \\
5 & 33 & 213,39 & 58 & 188,89 \\
6 & 33 & 219,03 & 48 & 217,63 \\
7 & 33 & 188,38 & 57 & 192.00 \\
8 & 33 & 209,00 & 50 & 209,00 \\
9 & 32 & 235,36 & 44 & 239,67 \\
10 & 32 & 255,00 & 35 & 0 \\
\hline
\end{tabular}

153 | P a g e 


\subsection{Quail Development by Using an Automatic Temperature Device}

\subsubsection{Quail first day}

On the first day te quail enters the bording cage is an adjustment phase, namely from the hatchery cage enters the bording cage. For a good quail reaction, tends to spread in the cage room, indicating that the temperature in the cage matches what is needed by quail seedlings. When the temperature is too high, the quail is more lazy or passive and inactive, at this stage the quail tends to be lazy. Figure 6

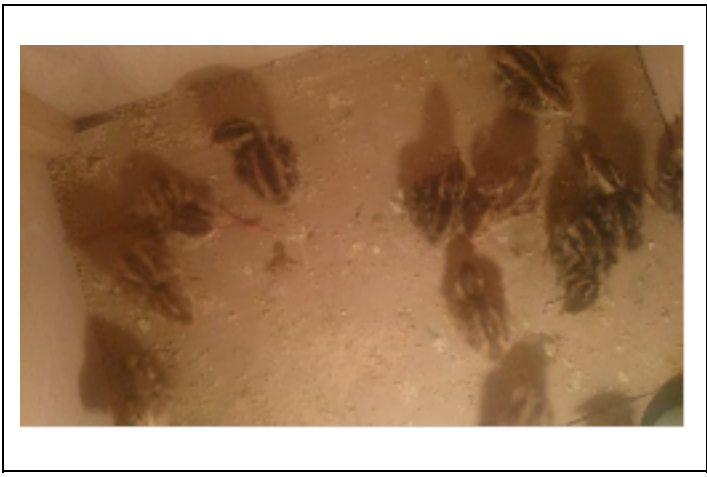

Fig. 6. Quail day one

\subsubsection{Quail day 7}

On the seventh day the feather on the quail body have grown almost evenly. In this phase the quail is more resistant to temperature changes. Figure 7

\subsubsection{Quail day 10}

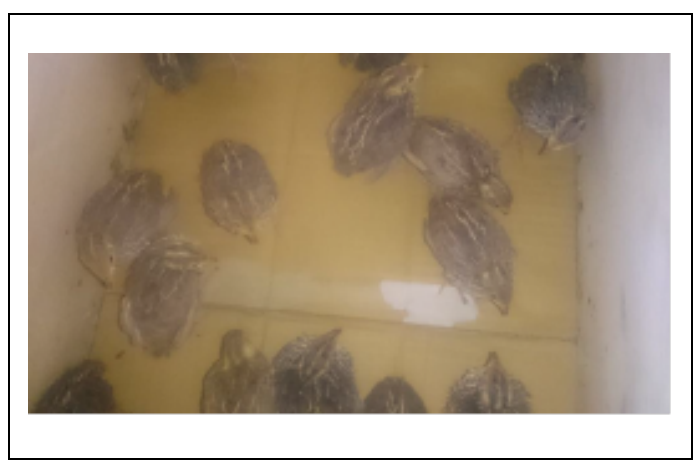

Fig. 7. Quail development day 7

After the ten-day-old quail the feathers on the body of the quail have grown almost perfectly. In this phase the quail is able to adjust the temperature of the room, so the quail is ready to be moved in the next phase which is the breeding cage without any more warmers. Figure 8

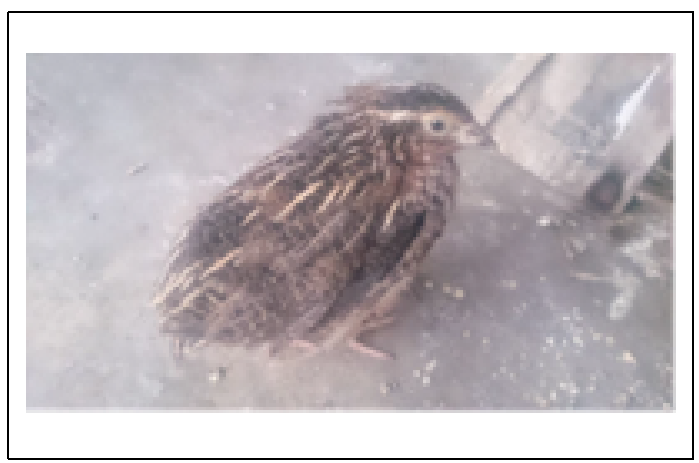

Fig. 8. Quail development day 10 
In temperature and humidity control experiments automatically, temperature tends to be more controllable, and temperature is more stable than manual temperature control. The success of the cage with temperature control is automatically higher than the temperature control manually, namely from the number of test samples of 10 quails in 10 days, the level of quail life is perfect or successful, namely 10 .

\section{Conclusion}

Based on the design and testing that has been done, it can be concluded that:

1. The application of fuzzy logic for determining temperature and humidity systems for hatching quail eggs is done by writing the Arduino program code which is arranged based on the rules of fuzzy logic calculation and the test results for the DHT sensor obtained an average percentage error for temperature of $1 \%$ and humidity of $2 \%$.

2. Overall the system can work well, namely the death rate of quails using fuzzy logic to control temperature, the mortality rate is $0 \%$ and without using fuzzy logic the mortality rate is $20 \%$

\section{References}

[1] A. Hasanudin, "PENGARUH SUHU PENETASAN TERHADAP FERTILITAS, DAYA TETAS DAN BERAT TETAS TELUR BURUNG PUYUH." Skripsi Yang Tidak Dipublikasikan, Universitas Hassanudin Makasar, 2017.

[2] R. H. Rahim, A. M. Rumagit, and A. S. M. Lumenta, "Rancang Bangun Alat Penetas Telur Otomatis Berbasis Mikrokontroler ATMega8535," J. Tek. Elektro dan Komput., vol. 4, no. 1, pp. 1-7, 2015.

[3] M. Z. Rodhi, D. Syauqy, and G. E. Setyawan, "Sistem Penentu Suhu Dan Kelembaban Incubator Telur Unggas Berdasarkan Berat Dan Warna Telur Menggunakan Metode Fuzzy," J. Pengemb. Teknol. Inf. dan Ilmu Komput. e-ISSN, vol. 2548, p. 964X, 2018.

[4] R. Arifuddin, D. R. Santoso, and O. Setyawati, "Pengembangan Sistem Akuisisi Data Nirkabel untuk Pengukuran Distribusi Suhu Bawah Permukaan,” J. EECCIS, vol. 9, no. 2, pp. 123-129, 2016.

[5] R. Arifuddin and Y. Sinatra, "Identifikasi Sensor Suhu pada Setup Awal Untuk Pengukuran Suhu Bawah Permukaan," JEECAE (Journal Electr. Electron. Control. Automot. Eng., vol. 3, no. 2, pp. 209-212, 2018.

[6] Y. Afriansyah, R. Arifuddin, and Y. Novrianto, "Rancang Bangun Alat Pendeteksi Detak Jantung, Suhu Tubuh, dan Tensimeter Berbasis Arduino Uno serta Smartphone Android," SinarFe7, vol. 1, no. 2, pp. 597-603, 2018. 
JEEMECS (Journal of Electrical Engineering, Mechatronic and Computer Science) ISSN 2614-4859

Vol. 3, No. 2, August 2020, pp. 149-156

d. https://doi.org/10.26905/jeemecs.v3i2.4354

\section{This page intentionally left blank}

156 | P a g e 